\title{
The Relationship Between SOFA, qSOFA, SIRS Criteria Scoring Systems and 1-Year Mortality in Patients Followed Up in Level 3 Intensive Care Unit after Orthopedic Surgery
}

\section{Ortopedik Cerrahi Sonrası Seviye 3 Yoğun Bakım Ünitesinde Takip Edilen Hastalarda SOFA, qSOFA, SIRS Kriter Puanlama Sistemleri ile 1 Yıllık Mortalite İlişkisi}

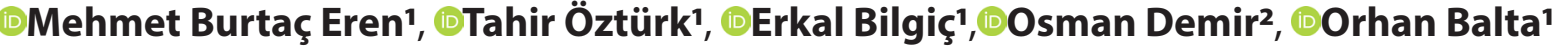

'Gaziosmanpasa University School of Medicine, Department of Orthopedics, Tokat, Turkey

${ }^{2}$ Gaziosmanpasa University School of Medicine, Department of Biostatistics, Tokat, Turkey

\begin{abstract}
Aim: Predictive scoring systems are designed to predict patients' discharge status, patient mortality, Intensive Care Unit(ICU) mortality and length of hospital stay. These scoring systems, which are aimed to standardize and form a common language in terms of evaluating patient general health situation, are used in the evaluation of patients in many ICU. In this study, we aimed to evaluate the ability of the scoring systems that can be used to predict the mortality of the patients who will be followed up in the ICU after orthopedic surgery and predict the mortality that occurs in the first year outside the hospital. We established our hypothesis that there will be no difference between the predictive power of predictive scoring systems, which can be used as a marker of mortality, since relatively short-term hospitalizations occur in the ICU after orthopedic surgery.

Material and Method:Ourstudy was designed as a single center retrospective. Between January 2017 and August 2018, all patients undergoing level 3 intensive care follow-up were identified in the automation system. After the evaluation of 146 patients' files and automation system data, patients who were in compliance with the inclusion and exclusion criteria were identified.

Result: A total of 40 patients were included in the study. The mean age was 75.69 (SD $=8.66$ years), $50 \%$ male and $50 \%$ female. Fifteen patients $(37.5 \%)$ died during their first year follow-up. When the patients were evaluated as survivors and non-survivors in the first year, it was observed that there was a significant difference between the groups in terms of quantitative variables in terms of early postoperative GCS and in terms of early postoperative oxygen saturation. There was no significant difference between the two groups in terms of qualitative variables ( $p>0.005)$.

Conclusion: An appropriate mortality predictor score should be selected to standardize follow-up in intensive care unit.As a result of our study, there was no significant relationship between groups SOFA, qSOFA scores and SIRS criteria met suggested that these scoring systems were not suitable for predicting 1-year mortality in our patient group. We believe that specific criteria should be established with studies with larger series and more criteria.
\end{abstract}

Keywords: SOFA score, qSOFA score, SIRS criteria, ICU mortality, orthopedic surgery

\begin{abstract}
Öz
Amaç: Mortalite skolarmaları; taburcu durumu, hasta mortalitesi, Yoğun Bakım Ünitesi (YBÜ) mortalitesini ve hastanede kalış süresini tahmin etmek için tasarlanmıştı. Hastanın genel sağlık durumunun değerlendirilmesi açısından standardize edilmesi ve ortak bir dil oluşturması amaçlanan bu puanlama sistemleri, birçok YBÜ'de hastaların değerlendirilmesinde kullanılmaktadır. Bu çalışmayla, puanlama sistemlerinin spesifik bir hasta grubunda kullanılabilirliği değerlendirilmesi amaçlanmıştır. Ortopedik cerrahi sonrası YBÜ'de nispeten kısa süreli hastaneye yatışlar meydana geldiğinden, mortalitenin bir göstergesi olarak kullanılabilecek tahmin edici puanlama sistemlerinin tahmin gücü arasında hiçbir fark olmayacağı hipotezimizi oluşturduk

Gereç ve Yöntem: Çalışmamız tek merkez retrospektif olarak tasarlandı. Ocak 2017 ile Ağustos 2018 arasında 3. seviye yoğun bakım takibi yapılan tüm hastalar otomasyon sisteminde belirlendi. 146 hasta dosyası ve otomasyon sistemi verilerinin değerlendirilmesinin ardından dahil etme ve dışlama kriterlerine uyan hastalar belirlendi.

Bulgular: Çalışmaya toplam 40 hasta dahil edildi. Ortalama yaş 75.69 (SD = 8.66 yıl),\% 50 erkek ve \% 50 kadındı. On beş hastanın (\% 37,5) ilk yıl içerisinde vefat ettikleri görüldü. Hastalar ilk yıl hayatta kalan ve kalamayanlar olarak değerlendirildiğinde, gruplar arasında kantitatif değişkenler açısından postoperatif erken GKS ve erken postoperatif oksijen satürasyonu açısından anlamlı farklılık olduğu görüldü $(p<0,005)$. Diğer hiçbir skorlama sistemi açısından anlamlı fark görülmedi ( $p>0,005)$.

Sonuç: Yoğun bakım ünitesinde takibi standartlaștırmak için uygun bir mortalite prediktör skoru seçilmelidir. Çalışmamız sonucunda SOFA, qSOFA ve SIRS kriterleri arasında anlamlı bir ilişki bulunmaması, bu skorlama sistemlerinin hasta grubumuzda 1 yıllık mortaliteyi öngörmek için uygun olmadığını düşündürdü. Daha geniş seriler ve daha fazla kriter içeren çalışmalarla ortopedik yoğun bakım hastalarına özgü spesifik kriterlerin oluşturulması gerekmektedir.
\end{abstract}

Anahtar Kelimeler: SOFA skoru, qSOFA skoru, SIRS kriterleri, yoğun bakım mortalitesi, ortopedik cerrahi 


\section{INTRODUCTION}

Predictive scoring systems are designed to predict patients' discharge status, patient mortality, Intensive Care Unit(ICU) mortality and length of hospital stay. These scoring systems, which are aimed to standardize and form a common language in terms of evaluating patient general health situation, are used in the evaluation of patients in many ICU.

It is considered important that such scores are obtained consecutively, especially at different times. In these scoring, evaluation is generally performed with the worst values among the recurrent follow-up.

It is known that many different predictive scoring systems have certain advantages and disadvantages.

SOFA (Sequential Organ Failure Assessment) score was primarily developed by an international cohort study from a series of 1449 patients in 40 different ICU to determine the severity of organ dysfunction in patients followed up for sepsis. ${ }^{[1]}$

Due to the high prevalence of multiple organ failure in critically ill patients in ICU, it has been used as a marker of mortality in many patients with organ failure. ${ }^{[2-5]}$

SOFA score consisted of $\mathrm{PaO}_{2}, \mathrm{FiO}_{2}$, mechanical ventilation requirement, platelet $\times 10^{3} / \mu \mathrm{L}$, Glasgow Coma Score(GCS), bilirubin level, mean arterial press and vasoactive agent requirement and creatinine levels.

In SOFA scoring, the mean value and the highest value during the day indicate better mortality. It has been reported that a $30 \%$ increase in scores leads to a $50 \%$ increase in mortality. ${ }^{[6]}$

qSOFA (quick SOFA) score is a scoring system proposed by the Society of Critical Care Medicine (SCCM) and the European Society of Intensive Medicine (ESICM) to predict early sepsis in non-intensive care patients. ${ }^{[7-9]}$ This method, which provides the advantage of bedside evaluation, is a highly applicable scoring system especially in the emergency department. $\left[{ }^{10,11]}\right.$ It can be used during daily patient visits in patients who are planned to stay in ICU unit after orthopedic surgery.

qSOFA score is based on whether the GCS is below 15 , the respiratory rate is 22 or above, and the systolic blood pressure is less than $100 \mathrm{mmHg}$, each of which is evaluated as one point.

SIRS (Systemic Inflammatory Response Syndrome) criteria include body temperature above 38 degrees, heart rate above 90 , respiratory rate above 20 or $\mathrm{PaCO}_{2}$ pressure below 32 $\mathrm{mmHg}, \mathrm{WBC}$ above 12,000 or below 4,000 , or predominance of $10 \%$ PMNL (Polymorphic Nucleus Leukocyte). Criterion positivity of 2 or more means that the SIRS criteria are met.

Patients followed up in the ICU after orthopedic surgery usually stay in the ICU for a short term. Analysis of the data obtained from vital follow-up as well as markers such as SOFA, q SOFA scores, SIRS criteria may also contribute to the evaluation of these patients with low in-hospital mortality and relatively short ICU stay.
In this study, we aimed to evaluate the ability of the scoring systems that can be used to predict the mortality of the patients who will be followed up in the ICU after orthopedic surgery and predict the mortality that occurs in the first year outside the hospital. We aimed to determine whether the current scores and the qualitative and quantitative variables to be obtained were significantly higher in the mortality group.

We established our hypothesis that there will be no difference between the predictive power of predictive scoring systems, which can be used as a marker of mortality, since relatively short-term hospitalizations occur in the ICU after orthopedic surgery.

We aimed to collect key data that may be related to a possible mortality prediction scoring system with the results to be obtained.

\section{MATERIAL AND METHOD}

Our study was designed as a single center retrospective. The study was conducted after obtaining permission from Gaziosmanpaşa University Clinical Research Ethics Committee (07.02.2020/20-KAEK-001).

Between January 2017 and August 2018, all patients undergoing level 3 intensive care follow-up were identified in the automation system. After the evaluation of 146 patients' files and automation system data, patients who were in compliance with the inclusion and exclusion criteria were identified.

\section{Inclusion criteria of the study:}

1. To be followed up in the $3 \mathrm{rd}$ level intensive care unit after orthopedic surgery

2. To be followed in the intensive care unit on the first postoperative day

3. Have enough recorded data to measure all predictive scoring values

\section{Exclusion criteria of the study:}

1. Under the age of 18

2. Patients taken into operation under emergency conditions

3. The need for follow-up in the intensive care unit in the preoperative period

4. Patient followed in the intensive care unit of a different center

5. The need for major surgery involving another clinic

40 patients who met the criteria were included in the study.

All evaluations were performed preoperatively, early postoperative and postoperative day 1. Vital follow-up, complate blood count, biochemistry, blood gas analysis results, GCS, whether vasopressor agent infusion was performed were recorded via hospital automation system, intensive care follow-up slips and patient archive files. 
As a result of this evaluation, it was recorded whether the patients qSOFA, SOFA scores and met the SIRS criteria in the preoperative period, early postoperative and postoperative 1st day. The patients were then divided into two groups as those with and without death in the first year. Preoperative - early postoperative - postoperative $1^{\text {st }}$ day SOFA, qSOFA, SIRS criteria were met between the groups with and without mortality in the first year and whether there was any difference in terms of quantitative and qualitative variables obtained.

\section{Statistical Analysis}

Descriptive analyzes were conducted to give information about the general characteristics of the study groups. Data of continuous variables were expressed as mean \pm standard deviation or median, interquartile range; categorical variables are given as $\mathrm{n}(\%)$. When comparing the means of the quantitative variables between the groups, independent samples t test or Mann Whitney $U$ test were used to determine the difference between groups. Cross-tables and chi-square tests are used to assess the relationship between qualitative variables. $p$ values less than 0.05 were considered statistically significant. In the calculations, ready-made statistical software was used (IBM SPSS Statistics 19, SPSS inc., An IBM Co., Somers, NY).

\section{RESULTS}

A total of 40 patients were included in the study. The mean age was 75.69 ( $S D=8.66$ years), $50 \%$ male and $50 \%$ female. Fifteen patients (37.5\%) died during their first year follow-up.

Patient data were classified as qualitative and quantitative.

Qualitative data; gender, Preoperative SIRS criterion, preoperative quick SOFA value, preoperative SOFA value, early postoperative SIRS criterion, early postoperative quick SOFA value, early postoperative SOFA value, postoperative SIRS criterion, postoperative SOFA value, postoperative SOFA value, early death, preoperative oxygen support, early postoperative oxygen support, postoperative oxygen support, whether or not intubated in the first 24 hours and these data were transferred to computer (Table 1).

Quantitative data was; preoperative respiration rate, early postop respiration rate, postop respiration rate, preoperative GCS, early postoperative GCS, postoperative GCS, preoperative oxygen saturation, early postoperative oxygen saturation, postoperative oxygen saturation and these data were transferred to computer (Table 2).

When the patients were evaluated as survivors and non-survivors in the first year, it was observed that there was a significant difference between the groups in terms of quantitative variables in terms of early postoperative GCS and in terms of early postoperative oxygen saturation. Early postoperative GCS and oxygen saturation were significantly lower in the group with mortality within 1 year period $(p<0.005)$ (Table 3 ).

There was no significant difference between the two groups in terms of qualitative variables ( $p>0.005$ ) (Table 4).

\begin{tabular}{|c|c|c|c|}
\hline Variables & & $\mathbf{n}$ & $\begin{array}{l}\text { Column } \\
\text { percent }\end{array}$ \\
\hline \multirow{2}{*}{ Gender } & Male & 20 & 50.0 \\
\hline & Female & 20 & 50.0 \\
\hline \multirow{2}{*}{ Preoperative met SIRS criteria } & No & 36 & 90.0 \\
\hline & Yes & 4 & 10.0 \\
\hline \multirow{3}{*}{ Preoperative qSOFA score } & 0 & 24 & 60.0 \\
\hline & 1 & 12 & 30.0 \\
\hline & 2 & 4 & 10.0 \\
\hline \multirow{6}{*}{ Preoperative SOFA score } & 0 & 1 & 2.5 \\
\hline & 1 & 21 & 52.5 \\
\hline & 2 & 13 & 32.5 \\
\hline & 3 & 1 & 2.5 \\
\hline & 4 & 3 & 7.5 \\
\hline & 5 & 1 & 2.5 \\
\hline \multirow{2}{*}{$\begin{array}{l}\text { Early postoperative met SIRS } \\
\text { criteria }\end{array}$} & No & 27 & 67.5 \\
\hline & Yes & 13 & 32.5 \\
\hline \multirow{4}{*}{ Early postoperative qSOFA score } & 0 & 14 & 35.0 \\
\hline & 1 & 18 & 45.0 \\
\hline & 2 & 7 & 17.5 \\
\hline & 3 & 1 & 2.5 \\
\hline \multirow{5}{*}{ Early postoperative SOFA score } & 1 & 9 & 22.5 \\
\hline & 2 & 20 & 50.0 \\
\hline & 3 & 6 & 15.0 \\
\hline & 4 & 4 & 10.0 \\
\hline & 5 & 1 & 2.5 \\
\hline \multirow{2}{*}{ Postoperative met SIRS criteria } & No & 27 & 67.5 \\
\hline & Yes & 13 & 32.5 \\
\hline \multirow{4}{*}{ Postoperative qSOFA score } & 0 & 14 & 35.0 \\
\hline & 1 & 18 & 45.0 \\
\hline & 2 & 7 & 17.5 \\
\hline & 3 & 1 & 2.5 \\
\hline \multirow{5}{*}{ Postoperative SOFA score } & 1 & 12 & 30.0 \\
\hline & 2 & 11 & 27.5 \\
\hline & 3 & 6 & 15.0 \\
\hline & 4 & 9 & 22.5 \\
\hline & 5 & 2 & 5.0 \\
\hline \multirow{2}{*}{ 1st year mortality } & Yes & 15 & 37.5 \\
\hline & No & 25 & 62.5 \\
\hline \multirow{2}{*}{$\begin{array}{l}\text { Preoperative receiving oxygen } \\
\text { support }\end{array}$} & Yes & 34 & 85.0 \\
\hline & No & 6 & 15.0 \\
\hline \multirow{2}{*}{$\begin{array}{l}\text { Early postoperative receiving } \\
\text { oxygen support }\end{array}$} & No & 7 & 17.5 \\
\hline & Yes & 33 & 82.5 \\
\hline \multirow{2}{*}{$\begin{array}{l}\text { Postoperative receiving oxygen } \\
\text { support }\end{array}$} & No & 14 & 35.0 \\
\hline & Yes & 26 & 65.0 \\
\hline \multirow{2}{*}{$\begin{array}{l}\text { To be followed intubated in the } \\
\text { first } 24 \text { hours postoperatively }\end{array}$} & No & 36 & 90.0 \\
\hline & Yes & 4 & 10.0 \\
\hline
\end{tabular}

Table 2. Distribution of Quantitative Variables Variables Mean SD Min Max

Preoperative respiratory rate per minute

Early postoperative respiratory rate per minute

Postoperative respiratory rate per minute

Preoperative GCS

Early postoperative GCS

Postoperative GCS

Preoperative oxygen saturation (\%)

Early postoperative oxygen saturation (\%)

Postoperative oxygen saturation (\%)

$\begin{array}{llll}20.75 & 2.43 & 16.00 & 28.00\end{array}$

$\begin{array}{llll}20.47 & 3.36 & 14.00 & 27.00\end{array}$

$\begin{array}{llll}19.47 & 3.64 & 12.00 & 28.00\end{array}$

$\begin{array}{llll}14.83 & .81 & 10.00 & 15.00\end{array}$

$\begin{array}{llll}14.15 & 1.39 & 10.00 & 15.00\end{array}$

$\begin{array}{llll}13.83 & 2.66 & 2.00 & 15.00\end{array}$

$\begin{array}{llll}96.25 & 2.83 & 90.00 & 99.00\end{array}$

$\begin{array}{llll}94.52 & 2.36 \quad 89.00 & 99.00\end{array}$

$\begin{array}{llll}94.88 & 2.29 & 90.00 & 99.00\end{array}$

Abbreviations: SD. Standard Deviation. Min. minimum. Max. maximum. GCS. Glasgow Coma Score 


\begin{tabular}{|c|c|c|c|}
\hline \multirow{2}{*}{ Variables } & \multicolumn{2}{|c|}{ 1st year mortality } & \multirow{2}{*}{$\mathbf{p}$} \\
\hline & Yes & No & \\
\hline Preoperative respiration rate per minute & $21.00 \pm 2.65$ & $20.6 \pm 2.33$ & 0.620 \\
\hline Early postoperative respiration rate per minute & $20.33 \pm 3.02$ & $20.56 \pm 3.61$ & 0.839 \\
\hline Postoperative respiration rate per minute & $19 \pm 4.34$ & $19.76 \pm 3.21$ & 0.529 \\
\hline Preoperative GCS & $15[15-15]$ & $15[15-15]$ & $0.619^{*}$ \\
\hline Early postoperative GCS & $14[12-15]$ & $15[15-15]$ & $0.001^{*}$ \\
\hline Postoperative GCS & $14[14-15]$ & 15 [14-15] & $0.088^{*}$ \\
\hline Preoperative oxygen saturation & $95.6 \pm 3.38$ & $96.64 \pm 2.43$ & 0.265 \\
\hline Early postoperative oxygen saturation & $93.47 \pm 2.47$ & $95.16 \pm 2.1$ & 0.026 \\
\hline Postoperative oxygen saturation & $94.27 \pm 2.31$ & $95.24 \pm 2.24$ & 0.197 \\
\hline
\end{tabular}

\begin{tabular}{|c|c|c|c|c|}
\hline \multirow{2}{*}{ Variables } & & \multicolumn{2}{|c|}{ 1st year mortality } & \multirow{2}{*}{$\mathbf{p}$} \\
\hline & & Yes (\%) & No (\%) & \\
\hline \multirow{2}{*}{ Gender } & Male & $10(66.7)$ & $10(40)$ & \multirow{2}{*}{0.102} \\
\hline & Female & $5(33.3)$ & $15(60)$ & \\
\hline \multirow{2}{*}{ Preoperative met SIRS criteria } & No & $14(93.3)$ & $22(88)$ & \multirow{2}{*}{0.586} \\
\hline & Yes & $1(6.7)$ & $3(12)$ & \\
\hline \multirow{3}{*}{ Preoperative qSOFA score } & 0 & $10(66.7)$ & $14(56)$ & \multirow{3}{*}{0.766} \\
\hline & 1 & $4(26.7)$ & $8(32)$ & \\
\hline & 2 & $1(6.7)$ & $3(12)$ & \\
\hline \multirow{6}{*}{ Preoperative SOFA score } & 0 & $0(0)$ & $1(4)$ & \multirow{6}{*}{0.716} \\
\hline & 1 & $8(53.3)$ & $13(52)$ & \\
\hline & 2 & $5(33.3)$ & $8(32)$ & \\
\hline & 3 & $0(0)$ & $1(4)$ & \\
\hline & 4 & $2(13.3)$ & $1(4)$ & \\
\hline & 5 & $0(0)$ & $1(4)$ & \\
\hline \multirow{2}{*}{$\begin{array}{l}\text { Early postoperative met SIRS } \\
\text { criteria }\end{array}$} & No & $9(60)$ & $18(72)$ & \multirow{2}{*}{0.433} \\
\hline & Yes & $6(40)$ & $7(28)$ & \\
\hline \multirow{4}{*}{ Early postoperative qSOFA score } & 0 & $4(26.7)$ & $10(40)$ & \multirow{4}{*}{0.098} \\
\hline & 1 & $5(33.3)$ & $13(52)$ & \\
\hline & 2 & $5(33.3)$ & $2(8)$ & \\
\hline & 3 & $1(6.7)$ & $0(0)$ & \\
\hline \multirow{5}{*}{ Early postoperative SOFA score } & 1 & $2(13.3)$ & $7(28)$ & \multirow{5}{*}{0.512} \\
\hline & 2 & $7(46.7)$ & $13(52)$ & \\
\hline & 3 & $3(20)$ & $3(12)$ & \\
\hline & 4 & $2(13.3)$ & $2(8)$ & \\
\hline & 5 & $1(6.7)$ & $0(0)$ & \\
\hline \multirow{2}{*}{ Postoperative met SIRS criteria } & No & $9(60)$ & $18(72)$ & \multirow{2}{*}{0.433} \\
\hline & Yes & $6(40)$ & $7(28)$ & \\
\hline \multirow{4}{*}{ Postoperative qSOFA score } & 0 & $5(33.3)$ & $9(36)$ & \multirow{4}{*}{0.592} \\
\hline & 1 & $6(40)$ & $12(48)$ & \\
\hline & 2 & $3(20)$ & $4(16)$ & \\
\hline & 3 & $1(6.7)$ & $0(0)$ & \\
\hline \multirow{5}{*}{ Postoperative SOFA score } & 1 & $3(20)$ & $9(36)$ & \multirow{5}{*}{0.693} \\
\hline & 2 & $4(26.7)$ & $7(28)$ & \\
\hline & 3 & $2(13.3)$ & $4(16)$ & \\
\hline & 4 & $5(33.3)$ & $4(16)$ & \\
\hline & 5 & $1(6.7)$ & $1(4)$ & \\
\hline \multirow{2}{*}{$\begin{array}{l}\text { Preoperative receiving oxygen } \\
\text { support }\end{array}$} & No & $12(80)$ & $22(88)$ & 0493 \\
\hline & Yes & $3(20)$ & $3(12)$ & 0.493 \\
\hline Early postoperative receiving & No & $4(26.7)$ & $3(12)$ & (237 \\
\hline oxygen support & Yes & $11(73.3)$ & $22(88)$ & 0.231 \\
\hline Postoperative receiving oxygen & No & $5(33.3)$ & $9(36)$ & 0864 \\
\hline support & Yes & $10(66.7)$ & $16(64)$ & 0.864 \\
\hline To be followed intubated in the & No & $12(80)$ & $24(96)$ & 0.102 \\
\hline first 24 hours postoperatively & Yes & $3(20)$ & $1(4)$ & \\
\hline
\end{tabular}

\section{DISCUSSION}

An appropriate mortality predictor score should be selected to standardize follow-up in intensive care unit. Intermittent review and revision of the selected marker may prevent deterioration of calibration and discrimination power. For special patient groups different markers should be selected.

For example, there are studies reporting that the Simplified Acute Physiology Score (SAPS) system, which is used as a general marker of morality, may be insufficient to predict mortality in patients with cancer or solid organ transplantation. ${ }^{[12,13]}$

An important criterion in determining the scoring system to be selected when performing intensive care mortality is time use. While performing our study, the selection of SOFA, qSOFA and SIRS criteria is the ease of use and the applicability of these criteria in daily practice.

The criteria which are indicators of mortality have a final score that will arise from the processing of the qualitative and quantitative data they contain. It has been shown in many studies that these scoring systems have different determinants in different ICU patient groups. ${ }^{[3,4,14-19]}$ Scoring systems containing qualitative and quantitative variables, which are found to be statistically significant after comparing the predictive mortality of the sub-parameters forming the scores, may be associated with the evaluation of the patient groups.

The severity of illnesses in the ICU is the most important predictor of hospital mortality, although there are several limitations of descriptive scoring systems. Since the developed scoring systems are formed in the light of the data obtained from intensive care patient groups, it is not appropriate to generalize by applying them to specific patient groups. ${ }^{[20-23]}$

As APACHE, MPM, SAPS 3, and SOFA scores showed quite mixed performance in studies conducted in different patient groups; development of special scoring systems including differentiated qualitative-quantitative variables for special patient groups has been seen as a need and various new classifications have been developed. Disease-specific mortality markers were developed following mixed results in groups of patients with cardiac surgery, liver failure, coronary artery disease, cardiac arrest, ECMO therapy, solid organ transplantation, and cancer. ${ }^{[2,3,14,17,18,24]}$ 
These mixed results led to the need for specific scoring systems for specific patient groups, and specific scores such as Global Registry of Acute Coronary Events (GRACE), European System for Cardiac Operative Risk Assessment (EUROSCORE2) and Cardiac Surgery Score (CASUS) were developed. ${ }^{[19,25]}$

Consistent with our hypothesis, there was no difference between the groups in terms of predicting 1-year mortality in terms of SOFA, qSOFA and SIRS criteria, and that these scores were not suitable for predicting 1-year mortality in patients with relatively shorter stay in intensive care unit after orthopedic surgery.

The guidance of these scoring systems is limited in longterm mortality assessment especially in patients who have been hospitalized in intensive care after orthopedic surgery. In most studies evaluating the performance of ICU predictive scoring systems, it is seen that the first 28-day inhospital mortality was evaluated. ${ }^{[26-29]}$ Studies evaluating the relationship with mid-long term and first one-year mortality are relatively few in number and include specific patient groups. ${ }^{[30,31]}$ Considering the results of our study, it was observed that there was no significant relationship between predictive scoring after orthopedic surgery and first year mortality. Although the findings of our study do not clarify this, it should be considered that this relationship may be significant in specific orthopedic surgery patient populations with high comorbidity.

Studies to determine the mortality of orthopedic patients are very limited and have examined quite different variables.

Peled et al. evaluated 147 orthopedic surgery and 39 urological surgery cases who had undergone urological or orthopedic surgery over 80 years of age, and reported that high ASA score, long surgery, major surgical intervention and length of surgery were risk factors for postoperative morbidity and mortality. ${ }^{[32]}$

In our study, none of the scores related to mortality were taken into consideration for ASA score, long surgery, major surgical intervention and length of surgery. Therefore, there may be no significant relationship between predictive scores and first-year mortality in our study. The magnitude of surgery performed in this patient group at or near critical illness level may also have an impact on early morbidity and mortality.

Chariyalertsak et al. examined the factors related to mortality after hip fracture in their series of 330 disease hip fracture disease in their patients; found male sex, presence of chronic disease, being over 80 years of age, poor walking potential before fracture and non-surgical follow-up as significant predictors of mortality. ${ }^{[33]}$

Adanır et al. reported age, ASA score 3 and above in geriatric intertrochanteric fracture patients, co-morbid disease was found to be significant on the first year mortality. ${ }^{[34]}$

Waikar et al. investigated the relationship between hyponatremia and mortality in their studies and found that there was a significant relationship between moderate- severe hyponatremia and mortality in patients hospitalized to perform cardiovascular disease, metastatic cancer and musculoskeletal procedures. ${ }^{[35]}$ Since the SOFA and qSOFA scoring systems exclude sodium levels, they cannot be expected to predict mortality associated with hyponatremia. This may be one of the reasons why these scoring systems are not associated with one-year mortality in our study.

If specific markers of mortality are developed for this patient group (geriatric hip fracture), which constitutes the majority of patients followed up in tertiary care after orthopedic surgery, it may be significant to determine the specific qualitative and quantitative variables, especially the gait potential and ASA score.

Chong et al. found that serum Pro-Brain Natriuretic Peptide (T ProBNP) levels were significantly higher in patients who underwent emergency lower extremity surgery in patients with postoperative complications and mid-term mortality. ${ }^{[36]}$ This value, which is an indicator of long-term congestive heart failure and indirect cardiac output, is not included in any scoring system. Assuming that cardiac output is particularly associated with long-term survival, scoring systems will remain incomplete in this respect.

Pulmonary hypertension is another independent risk factor associated with mortality after orthopedic surgery. Memtsoudis et al. Pulmonary hypertension was an independent risk factor for perioperative mortality in patients undergoing hip and knee arthroplasty surgery. ${ }^{[3]]}$ Pulmonary hypertension is also not a component of any predictive scoring system.

As a result of our study, there was no significant relationship between groups SOFA, qSOFA scores and SIRS criteria met suggested that these scoring systems were not suitable for predicting 1-year mortality in our patient group.

It seems necessary to develop a more specialized scoring system to predict one-year mortality, especially after orthopedic surgery.

The scoring system should include criteria such as walking potential, pro-BNP levels, pulmonary artery pressure, elevation of troponin levels, ASA score, size and duration of surgery.

To the best of our knowledge, we have conducted the first study in the literature examining the 1-year mortality with SOFA, qSOFA and SIRS criteria. The main limitation of our study appears to be the inadequacy of the sample size.

From the qualitative and quantitative data between the groups, the early postoperative GCS and low early postoperative oxygen saturation were significantly lower in the first year mortality group, which was associated with 1-year mortality; in particular, it demonstrates the need for a specific orthopedic intensive care patient determinant scoring system that incorporates these two criteria and all other relevant qualitative and quantitative data.

We believe that specific criteria should be established with studies with larger series and more criteria. 


\section{ETHICAL DECLARATIONS}

Ethics Committee Approval: Gaziosmanpasa University Clinical Research Ethical Comittee (07.02.2020, 20-KAEK001).

Informed Consent: Because the study was designed retrospectively, no written informed consent form was obtained from patients

Referee Evaluation Process: Externally peer-reviewed.

Conflict of Interest Statement: The author(s) declared no potential conflicts of interest with respect to the research, authorship, and/or publication of this article.

Financial Disclosure: The authors declared that this study has received no financial support.

\section{REFERENCES}

1. Vincent J-L, De Mendonça A, Cantraine F, et al. Use of the SOFA score to assess the incidence of organ dysfunction/failure in intensive care units: results of a multicenter, prospective study. Crit Care Med 1998;26:17931800.

2. Frohlich S, Murphy N, Conlon N. Predictors of outcome in decompensated liver disease: validation of the SOFA-L score. Ir Med J 2015;108:114-6.

3. Pan HC, Jenq CC, Tsai MH, et al. Scoring systems for 6-month mortality in critically ill cirrhotic patients: a prospective analysis of chronic liver failure-sequential organ failure assessment score (CLIF-SOFA). Aliment Pharmacol Ther 2014;40:1056-65.

4. Ñamendys-Silva SA, Texcocano-Becerra J, Herrera-Gómez A. Application of the Sequential Organ Failure Assessment (SOFA) score to patients with cancer admitted to the intensive care unit. Am J Hosp Palliat Care 2009;26:341-6.

5. Gilli K, Remberger M, Hjelmqvist H, Ringden O, Mattsson J. Sequential Organ Failure Assessment predicts the outcome of SCT recipients admitted to intensive care unit. Bone Marrow Transplant 2010;45:682.

6. Ferreira FL, Bota DP, Bross A, Mélot C, Vincent J-L. Serial evaluation of the SOFA score to predict outcome in critically ill patients. JAMA 2001;286:1754-8.

7. Singer M, Deutschman CS, Seymour CW, et al. The third international consensus definitions for sepsis and septic shock (Sepsis-3). JAMA 2016;315:801-10.

8. Seymour CW, Liu VX, Iwashyna TJ, et al. Assessment of clinical criteria for sepsis: for the Third International Consensus Definitions for Sepsis and Septic Shock (Sepsis-3). JAMA 2016;315:762-774.

9. Shankar-Hari M, Phillips GS, Levy ML, et al. Developing a new definition and assessing new clinical criteria for septic shock: for the Third International Consensus Definitions for Sepsis and Septic Shock (Sepsis-3). JAMA 2016;315:775-87.

10. Raith EP, Udy AA, Bailey M, et al. Prognostic accuracy of the SOFA score, SIRS criteria, and qSOFA score for in-hospital mortality among adults with suspected infection admitted to the intensive care unit. JAMA 2017;317:290-300.

11. Freund Y, Lemachatti N, Krastinova E,et al. Prognostic accuracy of Sepsis-3 criteria for in-hospital mortality among patients with suspected infection presenting to the emergency department. JAMA 2017;317:301-8.

12. Costa e Silva VT, de Castro I, Liano F, Muriel A, Rodríguez-Palomares JR, $\mathrm{Yu}$ L. Performance of the third-generation models of severity scoring systems (APACHE IV, SAPS 3 and MPM-III) in acute kidney injury critically ill patients. Nephrol Dial Transplant 2011;26:3894-901.

13. Maccariello E, Valente C, Nogueira L, et al. SAPS 3 scores at the start of renal replacement therapy predict mortality in critically ill patients with acute kidney injury. Kidney Int 2010;77:51-6.
14. Craig D, Reid T, Wright E, Martin K, Davidson J, Hayes P, Simpson K. The sequential organ failure assessment (SOFA) score is prognostically superior to the model for end-stage liver disease (MELD) and MELD variants following paracetamol (acetaminophen) overdose. Aliment Pharmacol Ther 2012;35:705-713.

15. Soares M, Salluh Jl: Validation of the SAPS 3 admission prognostic model in patients with cancer in need of intensive care. Intensive Care Med 2006;32:1839-44.

16. Oliveira VMd, Brauner JS, Rodrigues Filho E, et al. Is SAPS 3 better than APACHE II at predicting mortality in critically ill transplant patients? Clinics 2013;68:153-8.

17. Tsai CW, Lin YF, Wu VC, et al. SAPS 3 at dialysis commencement is predictive of hospital mortality in patients supported by extracorporeal membrane oxygenation and acute dialysis. Eur J Cardiothorac Surg 2008;34:1158-64.

18. Khwannimit B, Bhurayanontachai R. A comparison of the performance of Simplified Acute Physiology Score 3 with old standard severity scores and customized scores in a mixed medical-coronary care unit. Minerva Anestesiol 2011;77:305-312.

19. Nassar Junior AP, Mocelin AO, Andrade FM, et al. SAPS 3, APACHE IV or GRACE: which score to choose for acute coronary syndrome patients in intensive care units? Sao Paulo Med J 2013;131:173-8.

20. Barie PS, Hydo LJ, Fischer E. Comparison of APACHE II and III scoring systems for mortality prediction in critical surgical illness. Arch Surg 1995; 130:77-82.

21. Brown MC, Crede WB. Predictive ability of acute physiology and chronic health evaluation II scoring applied to human immunodeficiency viruspositive patients. Crit Care Med 1995;23:848-53.

22. Lewinsohn G, Herman A, Leonov Y, Klinowski E. Critically ill obstetrical patients: Outcome and predictability. Crit Care Med 1994;22:1412-4.

23. Sakr Y, Krauss C, Amaral AC, et al. Comparison of the performance of SAPS II, SAPS 3, APACHE II, and their customized prognostic models in a surgical intensive care unit. Br J Anaesth 2008;101:798-803.

24. Doerr F, Badreldin AM, Can F, Bayer O, Wahlers T, Hekmat K. SAPS 3 is not superior to SAPS 2 in cardiac surgery patients. Scand Cardiovasc J 2014;48:111-9.

25. Tsaousi G, Pitsis A, loannidis G, Pourzitaki C, Yannacou-Peftoulidou M, Vasilakos D. Implementation of EuroSCORE II as an adjunct to APACHE II model and SOFA score, for refining the prognostic accuracy in cardiac surgical patients. J Thorac Cardiovasc Surg 2015; 56:919-927.

26. Elbaih AH, Elsayed ZM, Ahmed RM, Abd-Elwahed SA. Sepsis patient evaluation emergency department (SPEED) score \& mortality in emergency department sepsis (MEDS) score in predicting 28-day mortality of emergency sepsis patients. Chin J Traumatol 2019;22:316322.

27. Jeong DH, Hong SB, Lim CM, et al. Comparison of accuracy of NUTRIC and modified NUTRIC scores in predicting 28-day mortality in patients with sepsis: a single center retrospective study. Nutrients 2018;10:911.

28. Bolia R, Srivastava A, Yachha SK, Poddar U. Pediatric CLIF-SOFA score is the best predictor of 28-day mortality in children with decompensated chronic liver disease. J Hepatol 2018;68:449-55.

29. Quach S, Hennessy DA, Faris P, Fong A, Quan H, Doig C. A comparison between the APACHE II and Charlson Index Score for predicting hospital mortality in critically ill patients. BMC Health Serv Res 2009;9:1-8.

30. Poukkanen $M$, Vaara ST, Reinikainen $M$, et al. Predicting one-year mortality of critically ill patients with early acute kidney injury: data from the prospective multicenter FINNAKI study. Crit Care 2015;19:1-11.

31. Agasthi $\mathrm{P}$, Ashraf $\mathrm{H}$, Pujari $\mathrm{SH}$, et al. Artificial Intelligence Trumps TAVI2-SCORE and CoreValve Score in Predicting 1-Year Mortality PostTranscatheter Aortic Valve Replacement. Cardiovasc Revasc Med 2021;24:33-41.

32. Peled E, Keren $Y$, Halachmi S, et al. Patients aged 80 and older undergoing orthopedic or urologic surgery: a prospective study focusing on perioperative morbidity and mortality. Gerontology 2009;55:517-22. 
33. Chariyalertsak $S$, Suriyawongpisal $P$, Thakkinstain A. Mortality after hip fractures in Thailand. Int Orthop 2001;25:294-297.

34. Adanır O, Albay C, Beytemür O. Relationship Between Mortality and Timing of Surgery in Elderly Intertrochanteric Hip Fractures. Eur Arch Med Res 2017;33:23-7.

35. Waikar SS, Mount DB, Curhan GC. Mortality after hospitalization with mild, moderate, and severe hyponatremia. Am J Med 2009;122:857-65.

36. Chong CP, Ryan JE, van Gaal WJ, et al. Usefulness of N-terminal pro-brain natriuretic peptide to predict postoperative cardiac complications and long-term mortality after emergency lower limb orthopedic surgery. Am J Cardiol 2010;106:865-72.

37. Memtsoudis SG, Ma Y, Chiu YL, Walz JM, Voswinckel R, Mazumdar M. Perioperative mortality in patients with pulmonary hypertension undergoing major joint replacement. Anesth Analg 2010;111:1110-6. 